To cite this article: Smith, A., Robbins, D., Dickinson, J.E. (2017) Defining sustainable transport in rural tourism: experiences from the New Forest. Journal of Sustainable Tourism. http://dx.doi.org/10.1080/09669582.2017.1401633.

\title{
Defining sustainable transport in rural tourism: experiences from the New Forest
}

Transport policy agendas have long sought to bring about more sustainable transport at tourism destinations. While there are examples of successes, it remains unclear what inroads have been made towards creating a sustainable transport future. Policy directions have evolved over a number of years and in many tourism destination contexts it is far from clear what a desirable transport future looks like. When translated to implementation, the aims of initiatives can be unclear and baseline measures inconsistent, making success difficult to judge. This paper analyses how sustainable travel has been implemented in practice at a destination level. The focus is rural tourism and data are derived from a specific case, the New Forest National Park, UK, where a wide range of transport initiatives have been implemented since the Park's designation in 2005. The study adopts a social practice theory perspective. Data are derived from a visitor survey, interviews and observations. It finds there is scope to improve sustainable transport provision at destinations through understanding visitor practices, but limited scope to influence meanings associated with visitor travel and travel skills. Policy meets the needs of some visitors more than others.

Keywords: rural tourism; sustainable travel; social practices; national parks

\section{Introduction}

The potential for motorised transport to detract from the rural tourism experience was identified well before the concepts of sustainable development and sustainable travel. For example, in the UK, the Dower committee cited visitor traffic as a key issue impacting on 'landscape beauty', 'peace and quiet' and 'enjoyment' (Dower, 1945 p25 in Cullinane, 1997), recommending restraint on traffic growth in national parks (Cullinane, 1997). Since these early warnings the volume of traffic in protected landscape amenity areas across the globe 
has grown rapidly (Holding, 2001) aligned with dramatic increases in road traffic, though now abating (Lyons, 2016), increasing leisure time (Organisation for Economic Co-operation and Development, 2010) and affluence (Paulley et al., 2006). As a consequence data indicates $80 \%$ of all day visits to the UK countryside are made by car (TNS 2016).

An interventionist policy approach has been adopted to address traffic volumes in rural destinations and to encourage a modal switch by visitors from car to 'more sustainable' modes of transport. Policy emphasis has changed over time from congestion and intrusion to place a greater emphasis on reducing greenhouse gas emissions (World Economic Forum, 2009). The sustainable development discourse embraced by transport policy is generally aligned to safeguarding long-term ecological systems (Beunen, Regnerus \& Jaarsm, 2008) and less towards social equity agendas that are often prevalent in utility transport contexts (Lucas, 2012). There have been several calls for more equity in leisure travel opportunities (for example, Dubois \& Ceron, 2006; Holden, 2007; Høyer, 2000) and the UK Government seeks to support National Park Authorities in removing transport barriers to access (Department for Environment, Food and Rural Affais, 2016).

Visitors to rural destinations will make several trips on a single day, sometimes using multiple modes of transport, with the journey often forming part of the overall experience (Lumsdon, Downward \& Rhoden, 2006). Visitors are typically seen as two homogeneous groups, day visitors and staying visitors, whereas there are many different segments of visitors within these two groups including very short distance, high frequency day visitors. Understanding the complexity of visitor travel requires a novel approach to data collection.

This paper draws on social practice theory (Shove, Pantzar \& Watson, 2012) to address the complexity of visitor travel. The paper analyses how sustainable travel has been implemented in practice at a destination level using the case of the New Forest National Park, UK. Focusing on visitor travel practices, the paper explores the extent to which these travel 
practices are sustainable, how well policy interventions align with these practices and investigates those visitors most susceptible to react positively to interventions. The scope of the paper is the tourism day visit, defined as a non-routine visit of three hours or more including travel time (TNS 2016). It excludes short duration leisure activities undertaken by local people in the vicinity of their homes.

\section{Policy approaches}

Despite an assumption that rural tourists might display relatively high levels of environmental awareness and be motivated to reduce their impact, the car share of tourism travel increases with rurality (Speakman, 2005). The car is the default modal choice for rural trips which can be attributed to remoteness of locations, the poor availability of public transport, both in terms of route density and frequency, the activities undertaken in the rural areas often requiring bulky equipment (for example, camping) and the absence of perceived problems of using cars for these trips. This presents major challenges to control levels of traffic to rural destinations and resident perceptions are that traffic-related problems in National Parks are getting worse (Dewhurst \& Thomas 2003).

A range of schemes have been implemented over many years. Research has identified a number of practical problems with these initiatives leading to individual failures, the most common cause being the short term nature of many schemes due to funding constraints (Cullinane \& Stokes, 1998: Dickinson \& Dickinson, 2006). Significant change in transport practice takes time to achieve.

The first approaches to control traffic levels were traffic management techniques, adapting strategies developed to manage traffic in urban areas (Cullinane, Cullinane, Fewings \& Southwell, 1995; Cullinane \& Cullinane, 1999). Traffic management strategies largely focussed on constraints and barriers to car use. They included road closure schemes often 
combined with bus or shuttle services (for example, the Upper Derwent Valley, Peak District National Park, UK or Zion National Park, USA), traffic calming and parking controls (Graham, 1998). Early research on the problem indicates that whilst such approaches addressed the worst problems at 'honeypot' visitor attractions, such as congestion and visual intrusion, they failed to reduce car travel to rural destinations or significantly reduce emissions and most were isolated, small initiatives (Cullinane, 1997). Many schemes also faced strong local opposition amidst fears of lost tourist revenue or personal inconvenience (Cullinane et al., 1995; Dickinson \& Dickinson, 2006).

Over time policy evolved to encourage modal shift, initially focused on encouraging public transport use. Examples include specialised tickets such as Wayfarer in West Yorkshire and Greater Manchester from 1983, or a specifically designed network of bus services such the Island Explorer in Arcadia National Park, USA (Holly, Hallo, Baldwin \& Mainella, 2010). The success of such schemes were measured using passenger numbers and ticket sales (Cullinane et al., 1995), whilst studies explored the motivations of users to switch mode from car to bus in order to develop strategies to further encourage and accelerate modal shift (Guiver, Lumsdon, Weston \& Ferguson, 2007; Lumsdon et al., 2006). Although some estimates of 'saved' car journeys were made, such as Moorbus in the North York Moors National Park (Robbins \& Dickinson, 2007), these constituted a very low share of the total car journeys and there was no robust systematic analysis of the benefits of such schemes. In the UK, The Transport Act 1998 (Department of Environment, Transport and the Regions, 1998) proposed a range of sustainable transport options for the UK which were then adopted and adapted for tourism journeys (Department of Culture, Media and Sport, 1999). Key policy objectives included 'to make it easier for people to make more informed decisions about their travel choices' (DCMS, 1999, p. 56) through 'a switch away from car to less 
polluting forms of transport' (DCMS, 1999, p. 57). However, the policy objectives were not developed beyond a desire to promote modal shift.

There is an assumption that modal switch from cars to alternative modes of transport must in itself be more sustainable, though there is potential for conflicting policy outcomes. For example, some bus service improvements have been funded on grounds of improved social access, and schemes that increase visitor arrivals, particularly from those without access to a car, without reducing the number of cars may increase $\mathrm{CO}_{2}$ emissions.

UK Government transport policy evolved further with the creation of the Local Sustainable Transport Fund (LSTF) (Department for Transport, 2011). LSTF funded 96 transport packages at a cost of $£ 1$ billion including Sustainable Transport Solutions for England's two newest National Parks, awarded jointly to the New Forest and the South Downs National Parks, one of a small number in rural areas. LSTF placed much greater emphasis on reducing transport emissions whilst continuing to achieve economic growth, and continued a focus on behavioural change.

One approach was to encourage modal shift to the tourist destination, making the car unavailable for use at the destination (DCMS, 1999). Alternative strategies accepted that the car is the most convenient mode of transport to the destination, with scope to severely limit its use whilst on the holiday. Examples include the development of tourist cards (for example, KONUS in the Black Forest, Germany) offering free public transport to tourists financed by a visitors tax (Durkop \& Gross, 2012).

A further approach is to encourage cycling, particularly for short journeys. Like modal shift to bus, there is an assumption this will generate environmental benefits. This fails to acknowledge the distinction between cycling as a mode of transport and cycling as a recreation activity. Previous studies have identified that in some instances cycling activities involve a car journey, with cycles carried on car racks, which generates motorised travel 
(Gale, 1996; Charlton, 1998; Dickinson \& Robbins, 2009), however, there have been no attempts to quantify this behaviour.

Despite the awareness of a need to restrain traffic growth at rural destinations dating from the mid-1940s, cohesive policy has not been implemented. Currently UK bus services are provided in a deregulated market dictated by commercial viability (see White 1995), which is ideologically inconsistent with a planned network. Whilst authorities have the ability to supplement the commercial market with socially desirable subsidised services, this fails to produce a co-ordinated network and provision is also severely constrained by financial resources. Over time some policies have become more integrated, combining incentives to use more sustainable modes with car restraint, but without producing the desired reduction in the car share, though there are isolated success stories (Guiver et al., 2007; Lumsden et al., 2006). To date the majority of studies have been atheoretical (Dickinson \& Dickinson, 2006), predominantly case studies (Cullinane, 1997; Holding \& Kreutner, 1998), piecemeal in approach, with a simplistic assumption that any modal switch is desirable while initiatives lack clear objectives for sustainable transport outcomes.

\section{Social Practice Theory}

More recently, studies have sought to bring theoretical perspectives to the fore to identify reasons for consumer's modal choices and the apparent failure to achieve widespread modal shift. There is an increasing awareness that traditional attitude and behaviour studies do little to generate understanding of transport decisions (Dickinson \& Dickinson 2006). They ignore various social, cultural and practical influences on consumers (Higham, Cohen, Peeters \& Gössling 2013) and suggest the need for a more comprehensive understanding of tourist transport use to inform policy-makers. One approach has been to explore how transport behaviours are shaped by the social representations that circulate in society, where practices 
become accepted and difficult to question (Dickinson \& Dickinson 2006: Dickinson \& Robbins, 2007) whilst other approaches include work on the role identities play in mobility decisions as high levels of mobility are portrayed in a positive light, irrespective of increasing consumer knowledge regarding the negative environmental impacts (Hibbert, Dickinson, Gossling \& Curtin, 2013). One promising route of enquiry to understand the complexity of travel is social practice theory (Cairns, Harmer, Hopkin \& Skippon, 2014) which is applied here to a rural destination context.

Social practice theory has its origins within the theory of structuration which links human behaviour with the wider social environment (see Giddens 1984). The theory of structuration recognises human activities as being "shaped and enabled by structures of rules and meanings; and these structures are at the same time reproduced by human activity" (Shove et al., 2012, p. 3). Interventions which aim to increase sustainability in the transport sector have focused on encouraging changes on an individual level (Cairns et al., 2014) sidestepping the underlying social structures that may strongly encourage forms of unsustainable mobility (Barr \& Prillwitz, 2012; Dickinson, Robbins \& Lumsdon, 2010). Shove (2010) argues that studies which focus on individual behaviours, tend to externalise, and therefore largely ignore, the context within which behaviour actually takes place. Ignoring this wider structural context fails to acknowledge that unsustainable behaviour may be 'locked-in' and therefore without addressing wider structural determinants, measures focused on encouraging behaviour change will have limited success (Hall, 2013).

Applying social practice theory places 'practices' at the focus of analysis. Reckwitz (2002) defines practices as "a routinized type of behaviour which consists of several elements, interconnected to one another: forms of bodily activities, forms of mental activities, 'things' and their use, a background knowledge in the form of understanding, know-how, states of emotion and motivational knowledge". Therefore, a practice is a block of activity or 
an 'entity' which is created and recreated by its repeated performance by individuals; the 'carriers' of practices. Individuals perform multiple social practices and these overlap, or bundle together or intercept to different degrees (Shove et al., 2012). Transitions in practices can occur as a result of changes in the constituent elements; changes in the carriers of practices or in the way that practices intercept with other practices (Watson, 2012).

Shove (2012) conceptualises social practices within the 'three elements model' consisting of:

1. Materials - The materials or infrastructure used to perform a practice. In transport this includes roads, rail networks, cars and bicycles.

2. Competences - The understanding, use of background knowledge, know-how. For example, being able to read a bus timetable or ride a bicycle.

3. Meanings - Motivations, beliefs. For example, the pleasure from riding a bicycle through countryside or the value of visiting a rural recreation site with family.

The model proposes that practices are dependent upon interrelations between these three elements and goes on to suggest that "if specific configurations [of practices] are to remain effective, connections between defining elements have to be renewed time and again" (Shove et al., 2012, p.24).

The three elements model has been adopted within this study as a framework for describing what constitutes a practice inclusive of the context within which it takes place, with the ultimate objective of understanding the sustainability of visitor transport in rural tourism. Here the practice is rural visiting for tourism purposes. Barr and Prillwitz (2012, p807) identify the need to "appreciate the different contexts and thus spaces in which activities such as sustainable travel are promoted" given that travel in a tourism context presents different attitudes and beliefs. Visitors use of transport in rural destination areas has been shown to embody meanings and competences which are very specific to this context, 
furthermore rural transport infrastructure ('materials') presents significantly different characteristics and challenges when compared to urban transport provision. Within rural tourism the intrinsic value ('meanings') of transport use is significant (Eaton and Holding, 1996; Lumsdon et al., 2006; Guiver et al., 2007; Lumsdon \& McGrath, 2011). Also, unlike daily commuting practices, rural visiting practices make use of transport on a less frequent basis and that degree of frequency will be reflected in the depth of visitor's knowledge of transport provision in this context ('competences').

Furthermore, just as multiple commuting practices exist (Cass \& Faulconbridge, 2016), so must multiple visitation practices as the term 'visitor' does not necessarily represent a homogenous group. Shove's model is therefore used to bring these three elements together whilst exploring the potential for variation in practices in this context.

\section{The New Forest}

The New Forest was designated as a National Park in 2005 but has a long association with conservation and recreation. The Park has an area of 570 square kilometres and incorporates internationally important wildlife habitats. The availability of trails through forest and open heathland provides a popular destination for informal outdoor recreation alongside a number of more formal visitor and heritage attractions. Wild ponies roam free across the Park and are a significant visitor attraction.

The New Forest is similar to other western European national parks (see Beunen et al., 2008) in that is does not represent a truly wild area, with in-situ resident populations and a landscape which reflects a long history of human influence. Furthermore, the Park is not remote from urban areas being situated between two large built up areas; Bournemouth and Southampton.

In 2012 and 2015 the New Forest National Park Authority and South Downs National Park with various partner authorities received Local Sustainable Transport Fund funding 
from the UK Department for Transport to implement sustainable transport initiatives alongside further funding to promote cycling within the Park. An increase in the proportion of visitors arriving to the National Park by sustainable modes and reduction in carbon emissions was sought (Hampshire County Council, 2012).

The New Forest represents a destination within which sustainable transport has evolved and continues to develop. The analysis of visitor travel practices within this setting provides an opportunity to review policy implementation and the relative success of the initiatives being implemented whilst allowing for reflection on the ultimate form that transport should take in protected landscapes.

\section{Methodology}

This research sought to identify the constituent elements of rural visiting practices, identifying aspects of sustainable travel and noting where policy interventions have enhanced this. The study employed a mixed methods approach which is consistent with a multi-level triangulation design (Tashakkori \& Teddlie, 1998) utilising three methods of data collection. A mixed methods approach raises epistemological concerns (Bryman, 2001), especially in a concurrent design. In this study each method sought to capture different aspects of visitor travel. A survey, building on an existing longitudinal study, sought to quantifying visitor characteristics and transport mode use patterns to understand trends in response to sustainable travel initiatives. Qualitative interviews and observations focused on understanding visitor experiences, their interactions with transport provision and the meanings associated with the visit. These qualitative methods provided an understanding of visitor travel practices, how they are sustained and how well policy interventions work with the established practices.

Quantitative data was collected through a visitor survey (n. 657) conducted between mid-July and mid-September 2015 at eight sites across the New Forest National Park (as listed in Table 5). The questionnaire was administered over 23 days by a commercial survey 
administration team, with some questionnaires administered by the lead author. Respondents were approached on a next to pass basis. Sites were carefully selected to meet a range of criteria including a sufficient volume of visitation as well as a cross-section of staying and day visitors. In addition the selected sites enabled a longitudinal comparison with previous National Park surveys.

The National Park Authority have surveyed visitors on an almost annual basis following an initial large study undertaken by Tourism South East in 2004 prior to the Park's designation. The 2004 survey incorporated over 70 survey sites and replication was too costly for subsequent surveys, especially as low numbers were captured at many sites. Subsequent visitor surveys have used fewer survey sites focused upon village centres and parking areas and the eight sites for the 2015 survey utilised sites from previous surveys enabling longitudinal analysis where appropriate, although new and additional questions were added to address limitations identified in the design of previous surveys.

The comprehensive 2004 survey presented some issues for understanding travel patterns. First, it captured many habitual short stay and short distance visits by local people, around $55 \%$ of day visitors reported visiting at least weekly (including $28 \%$ daily). The inclusion of small, peripheral, free car parks as survey sites captured a large proportion of routine dog walking trips made by the local population (Table 1). The aggregation of this group with 'tourism day visitors' and their inclusion in overall visitor statistics, which estimated 13.5 million 'visitor days' to the New Forest National Park in 2004 (Tourism South East, 2005) overstates the number of tourism visits to the National Park, the number of car journeys generated by tourism, and the level of car dependency.

A further limitation of previous questionnaire design is the focus on travel to the survey site which did not take into account the multi-site nature of the visitor day or the intermodality. The revised 2015 survey designed for this study collected information on visitor 
types (day visitor from home, visiting whilst staying with friends and relatives, visiting whilst on holiday), and was profiled by age and the presence of dogs. The visitor's activity and mode of travel to the survey site was recorded, alongside those of any previous and intended subsequent trips. For staying visitors, the mode of travel used to reach their accommodation at the beginning of their stay was recorded. This new approach was needed to provide more robust data on visitor travel patterns providing greater clarity with respect to visitor origins and their use of transport both to reach and to move around the National Park. The survey also recorded the visitor's final destination that day to understand any pass-through trips. Descriptive analysis of the data was undertaken using SPSS.

[Table 1 near here]

Two phases of semi-structured interviews were undertaken with visitors during the summers of 2015 and 2016. Interviews in 2015 focused on all transport activities, including origin and destination on the day of interview, whereas following analysis of the 2015 interviews, the further round of interviews conducted in 2016 explored the meanings visitors associated with their visit alongside their existing knowledge (competences) in much greater detail. For staying visitors, the 2016 interviews explored travel practices across the course of the whole stay rather than focusing on a single day. The visitor survey was used as a 'gateway' to talking to visitors in more depth in 2015 using an opportunistic sampling strategy. A total of 50 interviews were conducted (10 in 2015 over 2 days and 40 in 2016 over 3 days). Interviews were recorded in-situ and based around a series of open questions and were relatively short, lasting around 5-10 minutes. Interviews were transcribed and the analysis explored individual narratives to understand meanings and competencies associated with transport use in the New Forest. Subsequently thematic analysis sought to identify patterns across cases. 
Participant observation was employed to provide an understanding of visitors' interactions with and experiences of the transport provision available. Over the course of three years the lead author stayed at various locations in and around the New Forest National Park (Table 2) in order to gain an understanding of transport use from different visitor perspectives. The locations and activities were purposefully selected to gain insight into how structures can act to shape and influence practices. The use of participant observation can enhance both the quality of the data collected during field work and the interpretation of that data, whilst encouraging the formulation of new research questions (Dewalt \& Dewalt, 2011). These perspectives primarily focused on the experience of staying in the National Park itself and in the immediately surrounding areas. Day visits were also made from the nearby urban areas of Bournemouth and Southampton reflecting significant visitor flows. During these periods of immersion, the lead author made use of the available transport provision to support daily activities and also explored cycling options including trips with school age children. All modes of transport were used as available at the location and suited to requirements of the group members and activity being undertaken. Observations were recorded in notes which were analysed in conjunction with interview transcripts.

[Table 2 near here]

\section{Findings}

A more nuanced picture of visitor travel in the New Forest emerges from the 2015 data (see Table 3 for an overview). When data are compared for like survey sites from 2004 and 2015 it is evident some positive modal shift from car has been achieved (Table 4). Further analysis indicates several aspects need to be considered in more depth to understand potential 
sustainable transport gains and barriers: geographical location and transport availability; nature of trip; and group composition.

[Table 3 near here]

[Table 4 near here]

\section{Geographical location and transport availability}

In $2015,83 \%$ of all staying visitors surveyed travelled to their accommodation in private vehicles at the beginning of their stay, for those staying within the Park Boundary this increased to $92 \%$. Camping accommodation is predominant in the New Forest and, with the exception of a small number of camping pods, the vast majority of camping in the New Forest requires visitors to bring their own tents and equipment and hence cars to transport these items (Dickinson \& Robbins, 2007). However, visitors staying in catered accommodation present more scope for travel to the Park by rail as direct and frequent services are available from several large urban areas in the UK. Findings from the interviews and observations identified three barriers to rail travel for staying visitors: cost, the need to transport equipment and knowledge of rail services and ticketing:

“... what would be the cost of that? Is it cost prohibitive, I don't know. I would say it would be very costly, plus, on your own you would probably think about it. To the New Forest, we bring so much, you need your wellies and you have to bring so much. Surely if there is two of you it just pays to come in the car. Yes... be relaxing to do it, lovely and relaxing but..."

(Couple aged 45-54 from Shrewsbury, staying for three nights in a Bed and Breakfast Lyndhurst)

"It is quicker and less stressful for me to travel by train to Brockenhurst or Bournemouth as the service is direct from Leamington Spa. However, if I am bringing my daughter along too, the cost is too high so I travel by car. When I do 
travel by train it would be useful to be able to bring my bike but there are only three spaces on the train for bikes and to reduce the cost I need to book onto a specific train, if these spaces are already full I would not be able to board with the bike and my ticket would not be valid on other services."

(Lead author observation)

The researcher observed that she built competence in ticket buying strategies during the research project to reduce the cost of travelling by train. It was necessary to book in advance and to book the journey in multiple legs which then required the matching up of seat reservations to bring down the cost of the journey.

Whilst staying visitors relied on their cars to reach the New Forest there was more use of non-car modes to travel around the destination. Variation was evident between those visitors staying in the National Park, who exhibited lower car use, compared to those staying elsewhere (Table 5). Accommodation which is located within closer proximity to the village centres provides the greatest potential for car free travel with direct access to forest trails, shorter distances to local facilities and local public transport services. Approximately $70 \%$ of bed spaces within the Park boundary, including several large campsites, are remote from scheduled public transport services. Two further large holiday parks, located on the periphery of the Park (both marketed with reference to exploring the New Forest), are remote from public transport and from the Park's trails.

[Table 5 near here]

Non-car access to key New Forest sites from these peripheral locations is challenging despite various initiatives such as the New Forest Tour (a circular bus tour) which during the summer months, links three holiday parks and passes within walking distance of number of campsites. The tour provides three interlinking one-way loops of the Forest calling at all main attractions and villages. Despite this, the New Forest Tour is marketed as an 
'experience' as opposed to a bus service and users are expected to complete the whole loop. The marketing, ticket pricing structures and one-way circular routes resulted in the loss of additional bus link opportunities.

"I had taken the train to Brockenhurst and intended to board the New Forest Tour at the station to get to Burley Youth Hostel. I had been reassured by the visitor travel advisor that I could buy a single hop ticket. A couple were also attempting to use the Tour to get to their hotel in Burley. However, the driver was unable to provide single-hop tickets, reiterating to both myself and the couple that this was a tour." (Lead author observation whilst staying at Burley YHA August 2015)

The New Forest Tour offered the potential to provide bus travel between Brockenhurst and Burley. In 2015 the only bus serving Burley operated on summer weekends (this has since been withdrawn). Burley is a popular 'honeypot' site with several hotels, the New Forest's Youth Hostel and a cycle hire centre. The National Park Authority have since undertaken further negotiation with the Tour operator to make single hop tickets available but observations and interviews indicate they remain unadvertised and visitors are unlikely to be aware of their existence.

Significant variation in the proportion of all visitors arriving in private vehicles can be observed between survey sites reflecting the different transport choices available and the nature of the site with public transport shares at their highest for villages (Table 6). For example, Bolderwood provides a visiting experience which is not replicated elsewhere in the New Forest in that it offers toilet facilities, a barbeque area, open space, ranger services and a deer viewing platform. However, it is remote from public transport and is approximately $5 \mathrm{~km}$ and $6 \mathrm{~km}$ via roads and forest tracks from the nearest villages. 
"There are certain parts of the Forest you can get to like Brockenhurst and places like that but then they are not like this so you have to weigh up what you want from that trip to the Forest don't you really?"

(Family group visiting Bolderwood for the day by car from Southampton)

$21 \%$ of visitors surveyed identified cycling as an activity they would be taking part in during the course of their visit that day. Cycles therefore represent a material item of equipment that visitors would need to either hire or transport to the Park. Cycle hire is available from all of the village centres including a newly completed Family Cycling Centre adjacent to Brockenhurst Station that received funding in the recent initiative. Each cycle hire provider in each village operates independently requiring cycles to be returned to the point of origin, necessitating circular trips.

Cycles can be carried on trains but variation exists between individual train companies and a degree of competence is required to reserve spaces for cycles and understand where and how to load cycles within the limited time-frame for boarding. Visitors must also consider the journey from their homes to the station, with less confident or less-able cyclists unable to undertake this initial journey leg by cycle. For example:

“It's really our first ever visit to have a look around Brockenhurst isn't it? Yes, yes and we have been doing sort of a recce.... and we want to bring our bikes down here probably in September and we are investigating how to put them on the train because it's quite a drive down here, it's nearly 40 miles each way so it's 80 miles we might as well, alright we will have to pay for the train ticket next time, a normal day return but with our senior citizen's railcard we can probably get down here for about $£ 20 . £ 10$ each. And that's less than the price we would have to pay for bicycles, so we can bring our own bikes and they are free on the train which we found out." 
“...we only live about half an hour's walk from the station anyway at Fareham but if necessary we can take the car and put them in the back of the car and park near the Fareham railway station."

(Couple aged 65+ visiting for the day by train from Portsmouth)

Both day and staying visitors must also consider the cost of hiring bikes to use during their stay particularly if they already have their own cycles.

"We have in the past hired bikes but again it's a kind of added expense, particularly as we have bikes that we use quite frequently and are used to. I think my bike, I think is lighter, easier to ride than some of the bikes you can hire and so I prefer using my own bike."

(Couple aged 55-64 and 65+ staying in their motorhome at Ashurst campsite)

$67 \%$ of visitors who reported cycling as their activity at the survey site brought their own bikes with them to the New Forest and day visitors were less likely to be riding hired bikes.

[Table 6 near here]

\section{Nature of visit}

The survey data provides evidence of visitors combining car use with walking and cycling activities, utilising the network of small free parking areas. Many of these trips are circular and purely recreational although they may take in local sights and villages along the way. $12 \%$ of the survey respondents reported that they had stopped off somewhere else before arriving at the survey site and $42 \%$ planned to visit somewhere else before returning home or to their accommodation. $57 \%$ of visitors arriving on foot, by cycle or bus to survey sites undertook an initial journey by car from home or accommodation. Modal shares collected from a single spatial and temporal point therefore overlook car use that facilitates apparently sustainable modes of transport. 
How visitors used transport in the Park was influenced by the nature of their visit in terms of the planned activities. Lue, Crompton and Fesenmaier (1993) identified five spatial travel patterns that are typically adopted by visitors, these include visits to a single destination, visits made en route to another destination and shorter visits made from a 'base camp'. Picnic sites in the New Forest such as Bolderwood provided a focus for day visitors who stayed predominantly in one area for most of the day depending on the weather. Whilst the visit to this main site was planned, visitors could make more spontaneous decisions about the routes taken, stopping off and whether they may go on somewhere after.

"We might look for a country pub or something and just have a quick drink on the way home"

(Couple both aged 65+ on a day trip to Bolderwood from their home near Bournemouth)

The interviews highlighted how trips to the New Forest were linked with other purposes or were made whilst passing through the area en route to somewhere else:

“...we are now on our way home but they [the grandchildren] have stopped to go cycling, so we are having the day here"

(Couple both aged 90 visiting the New Forest before returning home from a holiday in Bournemouth)

“We went to Southampton to pick up a part for a vehicle that's being fixed and it's kind of our way through so we thought we would stop and get some food" (Mother aged 58 and Daughter aged 30 visiting as they pass through on their way home to Lymington and Ferndown)

Visits linked with other purposes or made en route to a different destination are less feasible without the use of private vehicles, although such visits may involve some element of walking or cycling as an activity. 
Visitors staying in the Park displayed 'base-camp' type characteristics, making trips from their accommodation to different destinations within or near the Park with the journey forming part of the recreation experience.

"We use cycling as our main means of communication, although we did use the bus yesterday... we came into Lyndhurst with the original intention of cycling to Brockenhurst but then we had a look at the route which was pretty well on the main road unless we wanted to do a really long one through the Forest and decided that that wouldn't be a very pleasant journey like that and so we said lets get on the bus" (Couple aged 55-64 and 65+ staying in their motorhome at Ashurst campsite)

Here the motorhome formed a very literal base as moving it during the stay risked losing the camping pitch. The couple made use of cycling, trains and the New Forest Tour during their stay.

\section{Group composition}

The ability for visitors to travel to on foot or on bicycle is dependent on the competences of all the group members. The capacity to cycle was observed to be limited by age, degree of fitness and confidence, particularly with respect to the need to cycle on road. Family groups with younger children staying in campsites were observed to use cycles recreationally, undertaking short circular rides in the Forest. The need to transport cycles by car to facilitate a cycle ride for younger/less confident/less fit cyclists was experienced by the researcher and identified within visitor interviews:

"Christine had hired a bike from the hire centre on site and so far, Josie (aged 10) had only used it around the holiday park. I wanted her to experience cycling in the Forest but I was uncertain of how she would manage to reach the Forest tracks given that it was a couple of miles requiring a long down-hill section on the road. In the 
end, we put two of the bikes in the car and I cycled down to meet them as it would have been a struggle to fit all three bikes in along with three passengers."

(Lead author observation staying at a Holiday Park, August 2014)

Whilst there is an extensive network of off-road tracks available for cycling, travelling between key destinations necessitates some cycling on busy roads where there is no specific provision for cyclists. For confident and/or regular cyclists, these busier sections can be more readily traversed but they represented an obstacle for other visitors, particularly family groups who were observed to ride along the very edge of the road, on the grass verges and on the pavements. This reflects the perception of cycling as an activity to be undertaken in 'safe' locations (Horton, 2007).

"it's just the main road out of Lymington, its unpleasant...we won't in total do more than 20-30 miles driving in a week within the Forest, we literally get to the first car park and unload...we see the car as a pain in a sense we are just wanting to be shot of it as soon as we can but very definitely not wanting to be [cycling] on open roads with heavy traffic dashing in and out of cars"

(Couple aged 45-54 staying in a cottage in Lymington)

Groups that included children reported higher car shares than adult only groups (Table 7), groups with children aged five showing greatest car use. Cycling with small children can limit the distance and time span over which a group can travel and more specialised equipment in respect of bicycle trailers is required. Adult only groups could cycle around the New Forest with greater ease and were able to use their bicycles both recreationally and practically but sought to avoid less pleasant on road sections.

[Table 7 near here]

\section{Visiting practices and transport use}


Using Shove's (2010) Three Element Model the findings have been used to explore the practices performed by visitors to the Park. Variation in practices exists with respect to how transport is incorporated into the rural tourism visit by different groups both in terms of origin, size and age profile of the group. This is discussed by mode.

\section{Walking}

Visitors travelling on foot represented a significant modal share for travel to village centres (Table 5). Walking is free and the relatively flat terrain in the Park requires no specialized equipment. Visitors on foot also benefit from open access to much of the Park and unlike cyclists are not confined to specific routes. Walking offers considerable flexibility in terms of distance and location and therefore presents more scope for combining with public transport and the New Forest Tour (which recommends suggested walks). Variations in walking practices make use of similar material elements, the trails and paths, whilst utilising cars, the network of car parks and public transport to reach the desired starting location. The meanings associated with walking are centred around a recreation experience representing an activity to be enjoyed during the visit and to be combined with other activities, for example family picnics in Bolderwood. For visitors staying within proximity to amenities it also provided a car-free form of transport. In terms of competences, the range or distance that visitors are able to walk was dependent on the ability and/or fitness of the group members. Smaller children and adults with more limited mobility were less able to cover distances but are also limited by other material aspects such as surfacing and gradient (Pezzo, 2010). Navigational competences were also required to different degrees.

\section{Cycling}


Visitors using hire bikes and visitors using their own bikes form distinct practices. Identifying the constituent elements of these practices highlights where these two practices diverge. With respect to 'meanings' for both groups, cycling in the Park is predominantly a recreation experience with both making use of forest tracks and avoiding busier on-road sections; unlike commuting, pleasantness is more important than directness or saving time. Cycling offers both groups the opportunity to enjoy the natural environment (Meschik, 2012). However, the own-bike cyclists were also able to use their bikes as a means of transport, this is particularly applicable to visitors staying within or close to the Park with their cycles being used from their 'base-camps' to visit different locations during their stay. Conversely, the material or structural elements of cycle hire shaped how the hire bikes are used. These structural elements included the requirement to return cycles to the point of origin within a specified time frame; the cost of hire (which represented a significant investment packaged as a day's activity reducing the likelihood that using hire bikes would be combined with other significant activities); and the provision of a route plan detailing a simple defined circular route.

In terms of competences, both cycle groups needed the ability to ride and the ability to undertake minor repairs, although for the hire bike users the hire company represented a safety net in the event of mechanical failures. Both groups would also need to be able to navigate, although hire bike users may choose to limit their movements with respect to the basic route plans supplied by some hire centres. Own bike cyclists needed to be able to transport their bikes to the Park. Cycling directly from home was mostly feasible only for local day visitors but for those living around the Park's periphery this initial leg into the Park may not be compatible with the desire for a pleasant recreation experience and would require cycling additional distance beyond the range of some groups of visitors. Hire bike users needed to be able to afford to use the service alongside the ability to reach the hire centres. 
Finally, both groups made use of the off-road tracks and to some extent the road network, however for the own bike users the availability of car parking to access the forest trails enabled transport of cycles to their preferred starting point.

\section{Driving}

Private vehicles can be seen to support walking and cycling activities in the Park. Private vehicles were also used in different ways to enable the overall visit. For staying visitors, cars were the cheapest mode of travel ignoring the sunk costs of vehicle ownership (Robbins \& Dickinson, 2007) and provided a means to carry equipment. Accommodation outside of the two main village centres remains largely inaccessible without the use of private vehicles hence car dependence has changed little for the transit journey. The greatest opportunities to maximise sustainable transport options are offered by accommodation close to village centres whereas visitors staying in large holiday parks on the periphery of the park present the greatest challenges. Cars played a similar supporting role for day visitors many of whom also brought equipment such as cycles or picnic items with certain popular New Forest sites being otherwise inaccessible. The material elements associated with driving included the availability of vehicles, the use of the road network and the free car parking provision. Competences included the ability to navigate, with some visitors identifying how they adapted their routes to avoid traffic congestion with more frequent visitors developing traffic avoidance strategies over time. With respect to meanings, some visits to the Park were opportunistic and made en-route to other destinations or combined with other activities in the vicinity. These visits to the Park still represented a recreation experience with most visitors taking part in typical tourism activities such as walking, visiting cafes and picnic sites. Visitors making the New Forest their principal destination for that day drew positive experiences from the drive through the Forest including the novelty of being held up by 
animals roaming into the road and the opportunity for more spontaneous stop-offs. Paradoxically visitors identified the negative aspects of congestion on their visitor experience.

\section{Conclusions}

Comparative visitor modal shares indicate that there has been a shift towards walking, cycling and public transport since the National Park's designation in 2005 (Table 4). However, the 2015 survey demonstrates that modal shares require careful interpretation, including the consideration of multi-site and multi-modal visits. A social practices framing of visitor transport use provides for a more contextualised understanding from which it is possible to reflect on the success of existing transport provision and inform further policy intervention. The extent to which walking, cycling and driving practices in their current form are sustainable is dependent on the aspect of sustainability that is addressed.

The Vision is for England's National Parks to be places where low carbon transport and travel are the norm (Defra, 2010). The UK Government called for a "renewed focus on achieving the Parks statutory purposes" and in doing so that they should "ensure they are exemplars in achieving sustainable development" (Defra, 2010, p. 11) which includes emission reductions through sustainable low carbon transport use (Defra, 2010). However, there are limitations to what a countryside provider can influence. While there is scope to improve the material provision at the destination by providing appropriate improved infrastructure informed by a better understanding of visiting practices, there is more limited scope to influence visitor meanings and competences and to influence travel to the destination.

Whilst there is an overarching emphasis on carbon reduction there is also a requirement to remove transport barriers to access and encourage more diversity amongst 
visitors. It is evident that policies and initiatives meet the needs of some visitors more than others. From an equity perspective, families with young children gain fewer benefits. The material provision for cycling requires certain competences that lock out groups like families due to ability levels and cost may lock the same group out of public transport use.

Low-carbon transport use in the Park is largely facilitated by cars as this makes sense from a visiting practice perspective. Analysis indicates visitors want to walk and cycle but this is not always feasible and some groups of visitors are locked in to using less sustainable transport modes either by their competence or by material provision as rural sites remain inaccessible to the majority without a car. Therefore it can be argued that car use, albeit reduced wherever possible, has an important role to play as a component of Mobility as a Service (MaaS) for inaccessible locations (Sochor, Karlsson \& Strömberg, 2016).

The extent of emissions relates to distance travelled and frequency of visit. Certain groups, such as local dog walkers, generate significant annual mileage given the daily and habitual nature of trips, and low average car occupancy. They will be little influenced by improved cycle facilities and public transport but maybe more impacted by restrictions such as parking restraints or charges.

Whilst tourists travel much further to the National Park relative to daily dog walkers, the social practices approach raises interesting questions regarding their sustainability. The distance travelled is short in comparison to international tourism and this form of tourism maybe more desirable and sustainable than the alternatives if the policy is to reduce the overall carbon footprint of tourism (see for example, Dubois \& Ceron, 2006). The frequency of trip is also low and the car occupancy is high at around three, reducing the per capita carbon footprint, and they also have a greater propensity to use alternatives to the car for travel around the Park (Table 3). Furthermore analysis indicates some tourist trips to the New Forest are combined with other trips, itself questioning what share of the emissions from 
a multi-purpose trip are appropriately attributed to the holiday trip to the New Forest. However the sustainable practices approach also identifies the limitations to reduce their car use further. The location of $70 \%$ of bed spaces inaccessible to public transport services combined with a requirement to carry heavy equipment for many tourists (such as campers) questions whether a much improved and dense public transport network can significantly reduce the $92 \%$ share of travel to NFNP by staying visitors.

Understanding of the travel associated with visiting practice is still rudimentary and the social practices approach adopted by this paper aids understanding and provides a theoretical approach to what has been, to date, a largely atheoretical, piecemeal case study approach. Visiting practices have evolved over time based on the system of provision, the visitor competences developed and the meanings associated with visits. These determine how people travel and where people go. Visiting practices are far from homogeneous. Visitors bring diverse competencies and it is clear that some visiting practices are more sustainable than others and transport strategies can be ineffective for some groups of visitors. Group composition influences the scope to utilise sustainable transport options, particularly the presence of young children.

One area where there is scope to reduce car dependency is day visitors to the New Forest National Park. The car share of $78 \%$ in 2015 (Table 3) includes visitors with good rail and bus access from surrounding urban conurbations such as Bournemouth and Southampton. Car remains the default option for these visits, however in part due to the lack of barriers for its use, particularly access to widespread free parking in the Park. Analysis has identified this as a group to target for decreased car dependency utilising appropriate infrastructure policies, particularly as there exists facilities for walking and cycling (with capacity to carry cycles on trains). There may be some material constraints on larger family groups making the modal 
switch due to increased cost. Nevertheless this is a segment with potential for a more desired transport future. 


\section{References}

Barr, S. \& Prillwitz, J. (2012). Green travellers? Exploring the spatial context of sustainable mobility styles. Applied Geography, 32, 798-809.

Beunen, R., Regnerus, H. \& Jaarsma, C. (2008). Gateways as a means of visitor management in national parks and protected areas, Tourism Management, 29 (1) $138-145$.

Bryman, A., 2001. Social Research Methods. Oxford, Oxford University Press.

Cairns, S., Harmer, C., Hopkin, J., \& Skippon, S. (2014). Sociological perspectives on travel and mobilities: A review. Transportation Research Part A: Policy \& Practice, 63, 107-117.

Cass, N., \& Faulconbridge, J. (2016). Commuting practices: New insights into modal shift from theories of social practice. Transport Policy, 45, 1-14.

Charlton, C. (1998). Public transport and sustainable tourism: The case of the Devon and Cornwall Rail Partnership, in: C.M. Hall and A.A. Lew (Eds) Sustainable Tourism, pp. 132145 (Harlow: Addison Wesley Longman).

Cullinane, S., (1997). Traffic management in Britain's national parks. Transport Reviews, 17, 267-279.

Cullinane, S., Cullinane, K., (1999). Attitudes towards traffic problems and public transport in the Dartmoor and Lake District National Parks. Journal of Transport Geography, 7, 7987.

Cullinane, S., Cullinane, K., Fewings, J. \& Southwell, J. (1995). Rural Traffic Management The Burrator Resevoir Experiment. Transport Policy, 3 (4) 213 - 224.

Cullinane, S. and Stokes, G. (1998) Rural Transport Policy. Oxford: Pergamon.

Department for Culture, Media and Sport (1999). Tomorrow's Tourism. London: Stationery Office.

Department for Environment, Food and Rural Affairs, (2016). 8-Point Plan for England's National Parks. London: Defra. 
Department for Environment, Food and Rural Affairs, (2010). English National Parks and the Broads UK Government Vision and Circular 2010. London: Defra.

Department of the Environment, Transport and the Regions (1998). A New Deal for Transport: Better for Everyone, Cm 3950, London: The Stationary Office

Department for Transport (2011). Creating Growth, Cutting Carbon - making sustainable local transport happen, Cm 7996, London: The Stationary Office.

DeWalt, K, \& DeWalt, B (2011). Participant Observation: A Guide For Fieldworkers AltaMira, Walnut Creek. USA.

Dewhurst, H. \& Thomas, R. (2003) Encouraging Sustainable Business Practices in a Nonregulatory Environment: A Case Study of Small Tourism Firms in a UK National Park, Journal of Sustainable Tourism, 11:5, 383-403.

Dickinson, J. E., \& Dickinson, J. (2006). Local transport and social representations: Challenging the assumptions for sustainable tourism. Journal of Sustainable Tourism, 14, 192-208.

Dickinson, J.E. \& Robbins, D. (2007). Using the car in a fragile rural tourist destination: A social representations perspective. Journal of Transport Geography, 15, 116-126.

Dickinson, J. E. \& Robbins, D. (2009). “Other People, Other Times and Special Places”: A Social Representations Perspective of Cycling in a Tourism Destination. Tourism and Hospitality Planning \& Development, 6(1), 69-85.

Dickinson, J.E., Robbins, D. \& Lumsdon, L. (2010). Holiday travel discourses and climate change. Journal of Transport Geography, 18, 482-489

Dubois, G. and Ceron, J.P. (2006). Tourism/leisure greenhouse gas emissions forecasts for 2050 Factors for change in France, Journal of Sustainable Tourism, 14(2), 172-191.

Durkop, D. \& Gross, S. (2012). Tourist Cards - Experiences with Soft Mobility in Germany's Low Mountain Ranges, BEST EN, Think Tank XII, Gréoux les Bains, France, available at http://www.besteducationnetwork.org/TTXII_Proceedings 
Eaton, B. \& Holding, D., (1996). The evaluation of public transport alternatives to the car in British National Parks. Journal of Transport Geography, 4, 55-65.

Gale, A., (1996). "Travelling Light" - rural sustainable transport policies for the 1990s and 2000s. In: Etchell, C. (editor), Today's thinking for tomorrow's countryside: recent advances in countryside recreation management, Proceedings of the Countryside Recreation Network annual conference 1995, 50-54.

Giddens, A. (1984). The constitution of society: Outline the theory structuration, Berkley, University of California Press.

Graham, A. (1998). United Kingdom in Transport and Leisure. Report of 111th Round Table on Transport Economics, European Conference of Ministers of Transport, Economic Research Centre, OECD.

Guiver, J., Lumsdon, L., Weston, R. \& Ferguson, M., (2007). Do buses help meet tourism objectives? The contribution and potential of scheduled buses in rural destination areas. Transport Policy, 14, 275-282

Hall, C. (2013). Framing behavioural approaches to understanding and governing sustainable tourism consumption: beyond neoliberalism, "nudging" and "green growth"? Journal of Sustainable Tourism 21 (7) 1091-1109

Hampshire County Council (2012). Sustainable Transport Solutions for England's two newest National Parks. Local Sustainable Transport Fund Application Form.

Hibbert, J. Dickinson, J.E., Gossling, S \& Curtin,S., (2013). Identity and tourism mobility: an exploration of the attitude-behaviour gap. Journal of Sustainable Tourism, 21, 999-2016.

Higham, J., Cohen ,S.A., Peeters,P. \& Gössling,S. (2013) Psychological and behavioural approaches to understanding and governing sustainable mobility, Journal of Sustainable Tourism, 21(7), 949-967.

Holden, E. (2007). Achieving Sustainable Mobility: Everyday and Leisure-time Travel in the $E U$. Aldershot: Ashgate. 
Holding, D. M. (2001). The Sanfte Mobilitaet project: Achieving reduced car-dependence in European resort areas. Tourism Management, 22, 411-417.

Holding,D.M \& Kreutner (1998) Achieving a balance between "carrots" and "sticks" for traffic in National Parks: the Bayerischer Wald project, Transport Policy, 5(3) 175-183. Holly, F., Hallo, J., Baldwin, E. \& Mainella, F. (2010). Incentives and disincentives for day visitors to park and ride public transportation at Acadia National Park. Journal of Park and Recreation Administration, 28, 74-93

Horton, D. (2007). Fear of cycling, in: D. Horton, P. Rosen and P. Cox (Eds) Cycling and Society, pp. 133-152 (Aldershot: Ashgate).

Hoyer, K.G. (2000). Sustainable tourism or sustainable mobility? The Norwegian case. Journal of Sustainable Tourism 8, 147-160.

Lucas, K., (2012). Transport and social exclusion: Where are we now? Transport Policy 20, $105-113$.

Lue, C., Crompton, J. \& Fesenmaier, D., (1993). Conceptualization of multi-destination pleasure trips. Annals of Tourism Research 20, 289-301.

Lumsdon, L., McGrath, P. (2011). Developing a conceptual framework for slow travel: a grounded theory approach, Journal of Sustainable Tourism, 19 (3), 265-279.

Lumsdon, L., Downward, P. \& Rhoden, S. (2006). Transport for Tourism: Can Public Transport Encourage a Modal Shift in the Day Visitor Market? Journal of Sustainable Tourism, 14 (2), 139-156.

Lyons, G. (2016). Transport analysis in an uncertain world. Transport Reviews, 36 (5), 553557.

Meschik, M. (2012). Sustainable Cycle Tourism along the Danube Cycle Route in Austria. Tourism Planning and Development, 9(1), 41-56.

Organisation for Economic Co-operation and Development (2010). OECD Statistics Extracts: Average hours actually worked per worker. Available at http://stats.oecd.org/Index.aspx?DataSetCode=ANHRS (accessed Aug 2010) 
Paulley, N., Balcombe, R., Mackett, R., Titheridge, H., Preston,J., Wardman,M., Shires, J. $\&$ White. P. (2006). The demand for public transport: The effects of fares, quality of service, income and car ownership. Transport Policy 13(4) 295 - 306.

Pezzo, K.A. (2010). Universal Access for Universal Value: Creating Disabled Access at Heritage Sites for those with Mobility Impairments. Conservation and Management of Archaeological Sites, 12(4), 290-323.

Reckwitz, A., (2002). Toward a Theory of Social Practices: A Development in Culturalist Theorizing. European Journal of Social Theory, 5(2): 243-263.

Robbins, D.K. \& Dickinson, J.E., (2007). Achieving domestic tourism growth and simultaneously reducing car dependency: the illusive prize. In: Peeters, P. (Ed.), Tourism and Climate Change and Mitigation: Methods, Greenhouse Gas Reductions and Policies. NHTV, Breda, pp. 169-187.

Shove, E., (2010). Beyond the ABC: Climate change policy and theories of social change. Environment and Planning A, 42, 1273-1285.

Shove, E., Pantzar, M. \& Watson, M. (2012). The Dynamics of Social Practice: Everyday Life and How it Changes. Sage Publications. London.

Sochor,J., Karlsson,S.A. Strömberg,H (2016) \& Trying Out Mobility as a Service Experiences from a Field Trial and Implications for Understanding Demand, Journal of the Transportation Research Board, Jan 2016, Vol. 2542, pp. 57-64.

Speakman, C. (2005). Tourism and Transport: Future Prospects. Tourism and Hospitality Planning and Development, 2 (2), 129-137.

Steiner, T.J. and Bristow, A.L. (2000) Road pricing in National Parks: A case study of theYorkshire Dales National Park. Transport Policy 7, 93-103.

Tashakkori, A, \& Teddlie, C (2010). Sage Handbook Of Mixed Methods In Social \& Behavioral Research. Edited By Abbas Tashakkori, Charles Teddlie, n.p.: Los Angeles: SAGE Publications. London. 
TNS (2016). The GB Day Visitor Statistics 2015. Edinburgh, TNS. Retrieved from: https://www.visitbritain.org/sites/default/files/vb-corporate/DocumentsLibrary/documents/England-documents/gbdvs_annual_report_2015_13.06.16.pdf

Tourism South East (2005). Visitor Survey of the New Forest National Park 2004-2005. TSE Research Report, Eastleigh.

Watson, M., (2012). How theories of practice can inform transition to a decarbonised transport system. Journal of Transport Geography. 24, 488-496.

World Economic Forum (2009). Towards a Low Carbon Travel and Tourism Sector, Davos, WEF.

White, P.R. (1995) Deregulation of local bus services in Great Britain: an introductory review, Transport Reviews, 15(2) 185 - 209. 
Table 1 Summary of day visitors by visit frequency (Tourism South East 2004 Visitor Survey)

\begin{tabular}{|c|c|c|c|c|c|c|}
\hline & $\begin{array}{l}\text { Sample } \\
\text { size }\end{array}$ & $\begin{array}{l}\% \text { by } \\
\text { travelling } \\
\text { to survey } \\
\text { site by car }\end{array}$ & $\begin{array}{l}\% \text { of } \\
\text { visiting } \\
\text { groups } \\
\text { with dogs }\end{array}$ & $\begin{array}{l}\% \text { visiting } \\
\text { site alone }\end{array}$ & $\begin{array}{l}\% \text { of adult } \\
\text { only } \\
\text { groups }\end{array}$ & $\begin{array}{l}\% \text { of visits } \\
\text { with a } \\
\text { duration of } \\
1 \text { hour or } \\
\text { less }\end{array}$ \\
\hline $\begin{array}{l}\text { Visit at least once daily } \\
\text { (year-round) }\end{array}$ & 648 & 88 & 81 & 57 & 91 & 67 \\
\hline Visit at least twice a week & 339 & 94 & 67 & 46 & 88 & 52 \\
\hline Visit at least once a week & 275 & 92 & 48 & 25 & 80 & 34 \\
\hline $\begin{array}{l}\text { Visit at least once a } \\
\text { fortnight }\end{array}$ & 224 & 91 & 32 & 18 & 78 & 32 \\
\hline Visit at least once a month & 292 & 94 & 23 & 17 & 75 & 28 \\
\hline $\begin{array}{l}\text { Less than } 12 \text { visits in last } 12 \\
\text { months }\end{array}$ & 106 & 93 & 18 & 7 & 71 & 25 \\
\hline $\begin{array}{l}\text { Less than } 6 \text { visits in last } 12 \\
\text { months }\end{array}$ & 229 & 92 & 19 & 12 & 71 & 27 \\
\hline $\begin{array}{l}\text { Only visited once or twice } \\
\text { in last } 12 \text { months }\end{array}$ & 120 & 86 & 23 & 10 & 73 & 33 \\
\hline Not visited in last 12 months & 63 & 86 & 13 & 6 & 71 & 24 \\
\hline
\end{tabular}


Table 2 Summary of observational research

\begin{tabular}{|c|c|c|c|c|}
\hline Base & Date Stay & $\begin{array}{l}\text { Length } \\
\text { Stay }\end{array}$ & Group Composition & Main activities \\
\hline $\begin{array}{l}\text { Holburne Bashley Holiday } \\
\text { Park }\end{array}$ & August 2014 & 7 days & $\begin{array}{l}\text { Alone } 3 \text { days } \\
\text { Son (aged 16) - } 2 \text { days } \\
\text { Adult friend - } 2 \text { days }\end{array}$ & $\begin{array}{l}\text { New Forest Tour. } \\
\text { Cycling- forest tracks. } \\
\text { Visitor attractions } \\
\text { (Reptile Centre \& } \\
\text { Lymington museum) } \\
\text { Key villages } \\
\text { (Brockenhurst and } \\
\text { Burley), } \\
\text { Cycling trip to the Isle } \\
\text { of Wight, }\end{array}$ \\
\hline Sandy Balls Holiday Park, & May 2015 & 7 nights & $\begin{array}{l}\text { Daughter (aged 12) } \\
\text { adult friend plus child } \\
\text { (aged 10) }\end{array}$ & $\begin{array}{l}\text { Cycling -forest tracks. } \\
\text { Cycling on road, } \\
\text { Cycle hire }\end{array}$ \\
\hline Shorefields Holiday Park, & August 2015 & 7 nights & $\begin{array}{l}\text { Daughter and friend } \\
\text { (both aged 12) } \\
\text { Son (aged 17) } \\
\text { Two adult friends }\end{array}$ & $\begin{array}{l}\text { New Forest Tour. } \\
\text { Cycle hire. } \\
\text { Walking. } \\
\text { Visits to Bournemouth }\end{array}$ \\
\hline Holmsley Campsite & August 2015 & 4 nights & Alone & Cycling- forest tracks. \\
\hline $\begin{array}{l}\text { Burley } \\
\text { (Youth Hostel) }\end{array}$ & August 2015 & 1 night & Alone & Local bus services \\
\hline $\begin{array}{l}\text { Bournemouth short stay } \\
\text { (Hotel in Bournemouth) }\end{array}$ & Feb 2016 & 1 night & Daughter (aged 13) & Cycle hire (half day) \\
\hline $\begin{array}{l}\text { Southampton } \\
\text { (AirBnB) }\end{array}$ & April 2016 & 2 nights & Adult friend & $\begin{array}{l}\text { Urban cycle routes. } \\
\text { Rail services). }\end{array}$ \\
\hline Roundhills Campsite & May 2016 & 3 nights & Daughter (aged 13) & $\begin{array}{l}\text { Kayaking and Archery } \\
\text { at activity centre } \\
\text { Cycling (own bike) }\end{array}$ \\
\hline $\begin{array}{l}\text { Burley } \\
\text { (Youth Hostel) }\end{array}$ & August 2016 & 6 nights & Alone & $\begin{array}{l}\text { Cycling to interview } \\
\text { destinations } \\
\text { Day visit to Milford on } \\
\text { Sea. }\end{array}$ \\
\hline $\begin{array}{l}\text { Burley } \\
\text { (Youth Hostel) }\end{array}$ & Oct 2016 & 2 nights & Alone & $\begin{array}{l}\text { Cycle - forest tracks } \\
\text { New Forest Tour }\end{array}$ \\
\hline
\end{tabular}


Table 3 Summary results from 2015 New Forest Visitor Survey

\begin{tabular}{|c|c|c|}
\hline Visit frequency & $\begin{array}{c}\text { Day Visitors (n.325) } \\
\% \\
\end{array}$ & $\begin{array}{c}\text { Staying visitors (n.332) } \\
\%\end{array}$ \\
\hline every day & 14 & 0 \\
\hline twice a week & 7 & 0 \\
\hline once a week & 11 & 0 \\
\hline once a fortnight & 13 & 0 \\
\hline once a month & 20 & 2 \\
\hline a few times a year & 28 & 28 \\
\hline not visited in the last 12 months & 5 & 44 \\
\hline not visited before & 2 & 25 \\
\hline \multicolumn{3}{|l|}{ Travel to accommodation at beginning of stay } \\
\hline Car, van, motorbike, campervan/motorhome & - & 83 \\
\hline Train & - & 4 \\
\hline Coach & - & 11 \\
\hline Other & - & 2 \\
\hline \multicolumn{3}{|l|}{ Travel to survey site } \\
\hline Car, van, motorbike, campervan/motorhome & 78 & 50 \\
\hline Public Transport (train, bus, New Forest Tour) & 4 & 8 \\
\hline Walking & 6 & 16 \\
\hline Cycling & 10 & 16 \\
\hline Minibus, coach, Twizzy, taxi, other & 2 & 10 \\
\hline Average car occupancy & 2.9 & 3.1 \\
\hline \multicolumn{3}{|l|}{ Visitor group profiles } \\
\hline Groups stopping off before visiting the survey site & 11 & 13 \\
\hline $\begin{array}{l}\text { Groups visiting somewhere else after the survey } \\
\text { site }\end{array}$ & 31 & 52 \\
\hline Average Group size & 3 & 5 \\
\hline Groups with children & 39 & 38 \\
\hline Groups with children aged five and under & 17 & 10 \\
\hline Groups with dogs & 36 & 23 \\
\hline
\end{tabular}


Table 4 Summary of modal shares to village centres July to mid-September 2004 and 2015

\begin{tabular}{|c|c|c|c|c|c|c|}
\hline & $\begin{array}{c}2004 \\
\text { Burley } \\
\text { Village } \\
\text { Centre } \\
\text { (n. 91) } \\
\%\end{array}$ & $\begin{array}{c}2015 \\
\text { Burley } \\
\text { Village } \\
\text { Centre } \\
(\text { n. } 110) \\
\%\end{array}$ & $\begin{array}{c}2004 \\
\text { Brockenhurst } \\
\text { Village } \\
\text { Centre } \\
\text { (n. 106) } \\
\%\end{array}$ & $\begin{array}{c}2015 \\
\text { Brockenhurst } \\
\text { Village } \\
\text { Centre } \\
(n .105) \\
\%\end{array}$ & $\begin{array}{c}2004 \\
\text { Lyndhurst } \\
\text { Village } \\
\text { Centre } \\
\text { (n. 119) } \\
\%\end{array}$ & $\begin{array}{c}2015 \\
\text { Lyndhurst } \\
\text { Village } \\
\text { Centre } \\
\text { (n. 130) } \\
\%\end{array}$ \\
\hline $\begin{array}{l}\text { Car, van, motorbike, } \\
\text { campervan/motorhome }\end{array}$ & 82 & 56 & 65 & 50 & 79 & 47 \\
\hline $\begin{array}{l}\text { Public Transport (train, } \\
\text { bus, New Forest Tour) }\end{array}$ & 3 & 13 & 7 & 10 & 3 & 10 \\
\hline Walking and Cycling & 9 & 19 & 28 & 41 & 11 & 26 \\
\hline $\begin{array}{l}\text { Minibus, coach, taxi, } \\
\text { other }\end{array}$ & 5 & 12 & 0 & 0 & 8 & 16 \\
\hline
\end{tabular}

(TSE Visitor Survey 2004 and NFNPA Visitor Survey 2015) 
Table 5 Staying visitor modal shares to survey sites (2015 NFNPA Visitor Survey)

\begin{tabular}{lccc}
\hline & $\begin{array}{c}\text { Staying within the Park } \\
\text { boundary } \\
\%\end{array}$ & $\begin{array}{c}\text { Staying in towns and } \\
\text { villages adjacent to the } \\
\text { NFNP } \\
\%\end{array}$ & $\begin{array}{c}\text { Staying in urban areas } \\
\text { near the NFNPA } \\
\%\end{array}$ \\
\hline $\begin{array}{l}\text { Car, van, motorbike, } \\
\text { campervan/motorhome }\end{array}$ & 45 & 65 & 48 \\
$\begin{array}{l}\text { Public Transport } \\
\text { (train, bus, New Forest Tour) }\end{array}$ & 7 & 7 & 9 \\
$\begin{array}{l}\text { Walking } \\
\text { Cycling }\end{array}$ & 25 & 6 & 0 \\
Minibus, coach, taxi, other & 22 & 13 & 5 \\
\hline $\mathrm{X}^{2}=102.507, \mathrm{df}=8, p=<.001$ & 1 & 9 & 38
\end{tabular}


Table 6 Summary of modal shares to survey sites (2015 NFNPA Visitor Survey)

\begin{tabular}{|c|c|c|c|c|c|c|c|c|}
\hline Travel to survey site & $\begin{array}{c}\text { Brockenhurst } \\
\text { Village } \\
\text { Centre } \\
\text { (n.105) } \\
\%\end{array}$ & $\begin{array}{c}\text { Burley } \\
\text { Village } \\
\text { Centre } \\
\text { (n. 110) } \\
\%\end{array}$ & $\begin{array}{l}\text { Lyndhurst } \\
\text { Village } \\
\text { Centre } \\
\text { (n. 130) } \\
\%\end{array}$ & $\begin{array}{c}\text { Bolderwood } \\
\text { (n. 84) } \\
\%\end{array}$ & $\begin{array}{c}\text { Keyhaven } \\
(\mathrm{n} .90) \\
\%\end{array}$ & $\begin{array}{c}\text { Lepe (n. 81) } \\
\%\end{array}$ & $\begin{array}{c}\text { Fritham } \\
\text { (n. 35) } \\
\%\end{array}$ & $\begin{array}{c}\text { Wilverley } \\
\text { Plain } \\
\text { (n. 21) } \\
\%\end{array}$ \\
\hline $\begin{array}{l}\text { Car, van, motorbike, } \\
\text { campervan/motorhome }\end{array}$ & 49 & 56 & 47 & 76 & 76 & 100 & 31 & 95 \\
\hline $\begin{array}{l}\text { Public Transport (train, } \\
\text { bus, New Forest Tour) }\end{array}$ & 10 & 13 & 10 & 0 & 2 & 0 & 0 & 0 \\
\hline Walking & 24 & 6 & 12 & 2 & 9 & 0 & 40 & 0 \\
\hline Cycling & 17 & 13 & 14 & 14 & 13 & 0 & 29 & 5 \\
\hline $\begin{array}{l}\text { Minibus, coach, taxi, } \\
\text { other }\end{array}$ & 0 & 12 & 16 & 8 & 0 & 0 & 0 & 0 \\
\hline
\end{tabular}

${ }^{1}$ not $100 \%$ due to rounding

$X^{2}=131.835, \mathrm{df}=15, p=<.001$ (excluding Fritham and Wilverley Plain) 
Table 7 Summary of modal shares to survey site for adult only groups and groups with children

\begin{tabular}{lcccc}
\hline & $\begin{array}{c}\text { Groups with } \\
\text { no children } \\
\text { (n. 405) } \\
\%\end{array}$ & $\begin{array}{c}\text { Groups } \\
\text { including } \\
\text { children aged } \\
\text { and under } \\
\text { (n. 90) } \\
\%\end{array}$ & $\begin{array}{c}\text { Groups } \\
\text { including } \\
\text { children aged } \\
6 \text { to 15 } \\
\text { (n. 112) } \\
\%\end{array}$ & $\begin{array}{c}\text { Groups with } \\
\text { children aged } \\
11-15 \\
\text { (n. 50) } \\
\%\end{array}$ \\
\hline Car/van/motorhome/motorbike & 59 & 81 & 77 & 54 \\
$\begin{array}{l}\text { Public Transport } \\
\text { Walking }\end{array}$ & 5 & 8 & 7 & 6 \\
$\begin{array}{l}\text { Bicycle (hired and own) } \\
\text { Other (including minibus and Twizzy and } \\
\text { coach) }\end{array}$ & 14 & 7 & 6 & 10 \\
\hline Average Car Occupancy & 7 & 3 & 1 & 23 \\
\hline
\end{tabular}

